\title{
Serum gonadotropins, cortisol, PSA, and micronutrient levels among men with prostate carcinoma
}

\author{
Wasiu Eniola Olooto ${ }^{*}$ (D), Abimbola Adeola Oyelekan², Omolara Oluwawemimo Adewole ${ }^{3}$, \\ Adeniyi Olugbenga Fajobi ${ }^{1}$, Ayyuub Abayomi Adedo ${ }^{4}$ and Oladipupo Olasimbo ${ }^{5}$
}

\begin{abstract}
Background: Prostate cancer (PrCa) is a malignant tumour of the prostate that has many associated risk factors. There is continuous rise in the incidence among adult blacks which is a reflection of racial differences in testosterone concentrations.

Methods: The study involves 50 PrCa patients attending or referred to two tertiary health Institutions and 25 healthy men as controls. Weight and height of participants were measured, and body mass index (BMI) was calculated. Ten millilitres of venous blood sample was collected from each participant, allowed to clot, and then centrifuged at $5000 \mathrm{rpm}$ for $5 \mathrm{~min}$ at room temperature $\left(22-28^{\circ} \mathrm{C}\right)$ to obtain the serum. Serum cortisol, testosterone, follicle-stimulating hormone (FSH), luteinizing hormone (LH), total prostate-specific antigen (TPSA), free prostate-specific antigen (FPSA), selenium, copper, magnesium, and zinc were determined. Prostate ultrasonography and biopsy were also done for histopathological studies.
\end{abstract}

Result: From this study, a significant increase $(p<0.05)$ in weight, BMl, serum FPSA, TPSA, and copper; a non-significant increase $(p>0.05)$ in serum cortisol, testosterone; a significant decrease $(p<0.05)$ in serum LH, selenium, zinc, and magnesium; and a non-significant decrease $(p>0.05)$ in serum FSH were observed among people living with PrCa when compared to the controls. However, no significant difference $(p>0.05)$ was observed in the height between the two groups. Ultrasonography and histology revealed evidence of prostatitis, hypertrophy, and carcinoma among the test group.

Conclusion: It can be concluded that PrCa is associated with increase serum cortisol, testosterone, and copper; and decreased serum LH, FSH, selenium, zinc, and magnesium concentrations and combination of biochemical, ultrasonographic, and histologic features are of diagnostic importance.

Keywords: Prostate, Testosterone, Cortisol, Gonadotropins, Trace elements

\section{Background}

Prostate cancer ( $\mathrm{PrCa})$ is the most commonly diagnosed cancer and a leading cause of cancer-related deaths among men in Nigeria [1]. The exact prevalence of PrCa

\footnotetext{
*Correspondence: olotoenny@yahoo.com

${ }^{1}$ Department of Chemical Pathology and Immunology, Faculty of Basic Medical Sciences, Olabisi Onabanjo University, Sagamu Campus, Sagamu, Nigeria

Full list of author information is available at the end of the article
}

in Nigerian population is not known, but in the USA the incidence was reported to be higher among adult black American men than white American men [2]. High incidence of $\mathrm{PrCa}$ among adult blacks is a reflection of racial differences in testosterone concentrations which has been found to be higher in Blacks than Whites during young adulthood, and the difference reduces with age and completely disappears after the age of 60 years [3]. 
Androgens notably testosterone, gonadotropins, oxidative stress, and reactive oxygen species (ROS) have been implicated in PrCa. In the prostate, testosterone is converted to a more potent intracellular androgen known as $5 \alpha$-dihydrotestosterone (DHT) by $5 \alpha$-reductase enzyme. The most bioavailable and active form of testosterone is the unbound or free testosterone form, while the remaining is primarily bound to sex hormone-binding globulin (SHBG), albumin, and corticosteroid-binding globulin with SHBG having the highest affinity for testosterone [4]. Reactive oxygen species boost PrCa development by activating transcription factor NF- $\mathrm{KB}$ through destruc-

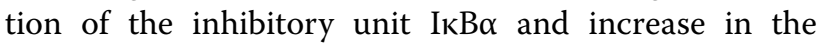
inflammatory cytokines, interleukins, and chemokines [5]. They are critical to tumour cell survival through the transduction pathways and play a crucial role in cell proliferation, angiogenesis, and metastasis [6].

In early course of $\mathrm{PrCa}$, the disease is rarely symptomatic, as it arises mainly in the peripheral portion of the prostate gland. Symptoms such as hesitancy, slowing of urinary stream, intermittent urine flow, haematuria, haematospermia, decreased ejaculatory volume, erectile dysfunction, and bony pain are present in situations of metastasis [7].

Diagnosing $\mathrm{PrCa}$ is a challenge usually confronted by urologist. Some of the employed diagnostic tools include digital prostate examination (DPE), serum prostate-specific antigen (PSA), ultrasonography (transrectal prostate scan), and prostate biopsy for histological studies. The availability of blood PSA screening test for the diagnosis of PrCa makes more people to have been diagnosed early enough before metastatic or advanced presentation rather than using DRE which makes patients to be diagnosed with more advanced disease. However, there are controversies on the use of PSA as screening and diagnostic tool and roles played by gonadotropins, cortisol, and antioxidants in the pathogenesis of PrCa. This study thus determined serum concentrations of these parameters in newly diagnosed PrCa patients.

\section{Methods}

\subsection{Study design}

The study is a case-control cross-sectional study involving 55 newly diagnosed $\mathrm{PrCa}$ patients attending or referred to two tertiary health Institutions and 25 healthy men as control subjects.

\subsection{Inclusion and exclusion criteria}

Included in the study were newly diagnosed PrCa patient as tests and healthy male subjects as controls. Excluded from the study were PrCa patients on medications, subjects with metabolic diseases such as diabetes mellitus, smokers, chronic alcoholics, participants with history of hard drug and antioxidant use, and those who did not consented to partake in the study.

\subsection{Clinical and physical examinations}

Prostate cancer was inferred clinically by the crossexamination of urologist and confirmed by laboratory investigations and histopathological studies. Physical examination was done on all participants with interest in pallor, poor or diffused urine stream during micturition, and weight loss. Manual palpation of the prostate for enlargement and consistency and regional lymph nodes for lymphadenopathy were also done (after blood sample collection). Weight and height of participants were measured using a weighing scale and stadiometer, respectively, and body mass index (BMI) was calculated using BMI $=$ Weight $(\mathrm{kg}) /$ Height $(\mathrm{m})^{2}\left(\mathrm{~kg} / \mathrm{m}^{2}\right)$. A questionnaire was administered to obtain data on demography, social habits, and urinary symptoms from participants.

\subsection{Blood sample collection}

Ten millilitres $(10 \mathrm{~mL})$ of venous blood sample was aseptically collected at $8 \mathrm{AM}$, after overnight fast, from the antecubital vein of each participant, transferred into a clean plain labelled tube, allowed to clot, and then centrifuged at $5000 \mathrm{rpm}$ for 5 minutes at room temperature $\left(22-28^{\circ} \mathrm{C}\right)$. The clear serum was separated and kept at $-20^{\circ} \mathrm{C}$ until assayed.

\subsection{Biochemical parameters}

Serum cortisol, testosterone, follicle-stimulating hormone (FSH), and luteinizing hormone ( $\mathrm{LH})$ were assayed by enzyme-linked immunoassay (ELISA) method using Accubind ELISA kits supplied by monobind Inc., USA, based on standard method [8-10]. Serum prostate-specific antigen (total and free) was determined by ELISA method using prostate-specific antigen ELISA kit supplied by Phoenix Pharmaceuticals Inc., USA. Serum copper, magnesium, and zinc were determined using atomic absorption spectrophotometry method, and serum selenium (Se) was determined using flameless graphite furnace atomic absorption spectrophotometry $[11,12]$.

\subsection{Prostate gland ultrasonography, biopsy, and histology}

Transabdominal prostate ultrasonography was done using SAMSUNG MEDISON SONOACE X6 with the patients positioned on the back, haven ensured a wellfilled urinary bladder which constitutes an "acoustic window" for the ultrasound waves penetrating the abdominal cavity to the prostate gland. The transducer was applied transversely just above the pubic symphysis, slid in a fanlike movement to search for the largest section of the prostate gland. 
Prostate biopsy was performed using a 18-gauge trucut needle which allows for obtaining bioptic specimens of $15 \mathrm{~mm}$ of length and $1 \mathrm{~mm}$ of diameter or thickness. The biopsy was aseptically performed in the treatment room with the tru-cut needles and the needle guide sterile and subjects given antimicrobial protection (oral ciprofloxacin $500 \mathrm{mg} 2$ times daily). The needle was placed in the automatic biopsy gun, which after loading (stretching the spring), unlocking and pressing the trigger allow for taking bioptic specimens. The prostate tissue was fixed in $10 \%$ formalin, dehydrated in $95 \%$ ethanol, and then cleared in xylene before embedded in paraffin. Micro-sections $(4 \mu \mathrm{m})$ were prepared and stained with haematoxylin and eosin (H\&E) dye and were examined under a light microscope by a histopathologist who was ignorant of the treatment groups.

\subsection{Ethical issue}

The ethics approval and consent to participate were obtained from the Research Ethical Committee of the teaching hospital, written informed consent was also obtained from all participants after the procedures, and potential benefits or risks had been explained to them at the beginning of the study. Participation was voluntary, and all information obtained was treated with utmost confidentiality.

\section{Data analysis}

The statistical analysis was done using statistical package for the social sciences (SPSS) software version 21. Descriptive statistics were used to describe and represent variables. Independent $t$ test was used to compare differences in mean between the two groups. The level of statistical difference was set at $p<0.05$.

\section{Results}

\subsection{Biophysical parameters}

Result of biophysical parameters showed a significant increase $(p<0.05)$ in weight and BMI, while there was no significant difference $(p>0.05)$ observed in the height among people living with $\mathrm{PrCa}$ when compared to the control group.

\subsection{Makers of prostate cancer}

Result of serum marker of PrCa revealed a statistically significant $(p<0.05)$ increase in serum FPSA, TPSA, and FPSA/TPSA ratio among people living with $\mathrm{PrCa}$ when compared to the control subjects.

\subsection{Serum hormones}

Result of serum hormones revealed a statistically significant $(p<0.05)$ decrease in serum LH; a non-statistically significant $(p>0.05)$ decrease in serum FSH; and a non-statistically significant $(p>0.05)$ increase in serum cortisol and testosterone among people living with $\mathrm{PrCa}$ when compared to the control subjects.

\subsection{Serum micronutrients}

Result of serum trace elements revealed a statistically significant $(p<0.05)$ decrease in serum selenium, zinc, and magnesium concentrations and a statistically significant $(p<0.05)$ increase in serum copper concentration among people living with $\mathrm{PrCa}$ when compared to the control subjects.

\subsection{Ultrasonography and histology}

The ultrasonogram showed normal sized prostate with homogeneous echotexture and regular outline among the controls and enlarged prostate with heterogeneous echotexture and irregular outline among some members of the PrCa group. Also, result of histological studies showed features of adenocarcinoma among some members of PrCa group and features of atrophic changes in others.

\section{Discussion}

Obesity (BMI $\left.>30 \mathrm{~kg} / \mathrm{m}^{2}\right)$ is associated with an increased risk of several cancers, but conflicting results have been reported by researchers on the association between BMI and risk of PrCa. While some reported a significant interaction between BMI and PrCa [13], others reported no association between height, BMI, and risk of $\mathrm{PrCa}$ [14]. Result obtained from this study showed a significant increase $(p<0.05)$ in weight and BMI among people living with PrCa when compared to the control group (Table 1). However, no significant difference $(p>0.05)$ was observed in the height between the two groups. These findings are in support of the work of some researchers $[13,14]$. In the recent time, some associations have been found to exist among other indicators such as waist circumference (WC), waist-hip ratio (WHR), and abdominal obesity [15]. The predictive effect of BMI on the risk of PrCa is strongly determined by genetic susceptibility of individuals to having the disease. It is worthy of note that obesity

Table 1 Biophysical parameters of the prostate cancer patients and controls

\begin{tabular}{lrrll}
\hline Parameters & \multicolumn{1}{l}{ Test } & \multicolumn{1}{l}{ Control } & t value & $\boldsymbol{p}$ value \\
\hline Weight $(\mathrm{kg})$ & $72.56 \pm 1.38$ & $65.14 \pm 1.41$ & 3.39 & 0.001 \\
Height $(\mathrm{m})$ & $1.62 \pm 0.01$ & $1.61 \pm 0.01$ & 0.948 & 0.345 \\
$\mathrm{BMI}\left(\mathrm{kg} / \mathrm{m}^{2}\right)$ & $27.64 \pm 0.46$ & $25.24 \pm 0.58$ & 3.092 & 0.003 \\
\hline
\end{tabular}

This table shows weight, height, and BMI among people living with PrCa and control groups. Values are Mean \pm Standard error of mean, and statistically significant difference was set at $p<0.05$ 
might have a detrimental effect on screening for PrCa by lowering serum PSA concentrations in obese men, who also tend to have larger prostates, making detection by transrectal ultrasound-guided biopsy more difficult [16].

Markers of predictive importance in PrCa include prostatic acid phosphatase (ACP), prostate-specific antigen (TPSA and FPSA), prostate-specific antigen density (PSAD), prostate-specific antigen velocity (PSAV), and prostate health index (PHI). Blood PSA concentration is usually explored to screen, detect, and monitor progression and treatment response. However, PSA is of low sensitivity and specificity in identifying $\mathrm{PrCa}$, being known to increase in other prostate pathological conditions such as $\mathrm{BPH}$ and prostatitis. Using TPSA, PrCa is diagnosed with values $>4 \mathrm{ng} / \mathrm{mL}$, while values in the range of $4.0-10.0 \mathrm{ng} / \mathrm{mL}$ have been described as a diagnostic "Grey-Zone" which necessitate prostate biopsy. The result obtained from this study revealed a statistically significant increase $(p<0.05)$ in serum FPSA and TPSA among people living with $\mathrm{PrCa}$ when compared to the control subjects (Table 2). Similar finding had earlier been reported in a similar study [17]. High concentration of free inactive PSA is associated with increased likelihood of benign prostate hypertrophy $(\mathrm{BPH})$ rather than PrCa $[18,19]$. The observed high serum total PSA (free and complexed PSA) concentration and free PSA among people living with $\mathrm{PrCa}$ indicate some degree of hyperplastic changes in the epithelial cells of the prostate gland which result in increased secretions into the lumen and some degrees of dysplasia that is pathognomonic of PrCa. Free-to-total PSA ratio is employed to improve the specificity of total PSA for "Grey-Zone", to determine the relative risk of $\mathrm{PrCa}$ and selection of men to benefit from prostate biopsy. Value of free-to-total PSA ratio obtained from this study revealed a non-significant increase $(p>0.05)$ among people living with $\operatorname{PrCa}$ when compared to the control subjects. This indicates existence of $\mathrm{PrCa}$ among the test group.

Result of serum hormone obtained from this study showed a non-significant increase $(p>0.05)$ in serum cortisol among people living with $\mathrm{PrCa}$ when compared with the control group (Table 3). This finding

Table 2 Serum marker of prostate cancer among prostate cancer patients and controls

\begin{tabular}{lrlll}
\hline Parameters & \multicolumn{1}{l}{ Test } & Control & T value & $\boldsymbol{p}$ value \\
\hline FPSA $(\mathrm{ng} / \mathrm{mL})$ & $1.74 \pm 0.10$ & $0.55 \pm 0.05$ & 7.514 & 0.000 \\
TPSA $(\mathrm{ng} / \mathrm{mL})$ & $48.84 \pm 3.57$ & $2.03 \pm 0.04$ & 8.813 & 0.000 \\
FPSA/TPSA & $0.59 \pm 0.54$ & $0.27 \pm 0.03$ & 0.391 & 0.697 \\
\hline
\end{tabular}

This table shows serum marker of prostate cancer among prostate cancer patients. Values are Mean \pm Standard error of mean, and statistically significant difference was set at $p<0.05$
Table 3 Serum hormone among prostate cancer patients and controls

\begin{tabular}{lcccc}
\hline Parameters & \multicolumn{1}{l}{ Test } & \multicolumn{1}{l}{ Control } & T value & $\boldsymbol{p}$ value \\
\hline Cortisol $(\mathrm{ng} / \mathrm{mL})$ & $0.89 \pm 0.04$ & $0.87 \pm 0.08$ & 0.192 & 0.849 \\
$\mathrm{LH}(\mathrm{mlU} / \mathrm{mL})$ & $6.72 \pm 0.53$ & $13.33 \pm 0.61$ & -7.472 & 0.000 \\
FSH $(\mathrm{mlU} / \mathrm{mL})$ & $10.26 \pm 0.81$ & $12.11 \pm 0.60$ & -1.457 & 0.149 \\
Testosterone $(\mathrm{mlU} / \mathrm{mL})$ & $1.12 \pm 0.07$ & $1.05 \pm 0.13$ & 0.529 & 0.598 \\
\hline
\end{tabular}

This table shows serum hormones among PrCa patients. Values are Mean \pm Standard error of mean, and statistically significant difference was set at $p<0.05$

is consistent with previous studies and indicates the contribution of cortisol to $\mathrm{PrCa}[20,21]$. The observed hypercortisolism could be due to activation of hypothalamic-pituitary-adrenal (HPA) axis which stimulates tumour or causes immunosuppression, thereby influencing the progression of $\mathrm{PrCa}[22,23]$. Cortisol in synergy with other hormones such as estradiol, leptin, and insulin acts to stimulate $\mathrm{P}_{450}$ aromatase resulting in increased aromatase activity which leads to increased intracellular oestrogen, abdominal fat deposition, and PrCa [20, 24, 25].

There are conflicting reports on the role of endogenous testosterone in the pathogenesis of $\mathrm{PrCa}$. Some studies reported elevated testosterone [26, 27], and some reported lower testosterone [28, 29], while some reported no association of testosterone with PrCa risk $[30,31]$. However, serum testosterone can be measured as a therapeutic target to verify response to androgen deprivation therapy (ADT) and ensure that castration levels are achieved during ADT [32]. Result obtained from this study revealed a non-significant increase $(p>0.05)$ in serum testosterone among people living with $\mathrm{PrCa}$ when compared with the control subjects (Table 3). This corroborates the earlier reported increased testosterone concentrations in $\mathrm{PrCa}[26,27]$. This observation provides answer to the frequently asked questions of whether testosterone promotes $\mathrm{PrCa}$ pathogenesis in humans or not. Meanwhile, serum testosterone level was reported to decline with age, increasing body mass index, and presence of chronic illness [33-36].

The involvement of gonadotropin-releasing hormone (GnRH), FSH, and LH in PrCa has also been suggested. Studies in human revealed that benign and malignant prostate cell produces both FSH and its receptor with a likelihood of increased FSH receptor gene expression in $\mathrm{PrCa}$ cells [37]. The testes and prostate produce prostatic inhibin peptide (PIP) which is an important modulator of the FSH pathway that decreases production and secretion of FSH by both the anterior pituitary 
and prostate glands [38]. Considering serum gonadotropin concentrations, result obtained from this study revealed a non-significant decrease $(p>0.05)$ in serum FSH and a significant decrease $(p<0.05)$ in serum LH among people living with $\mathrm{PrCa}$ when compared with the control subjects (Table 3). The observed decreased serum FSH and LH concentration corroborate that of other researchers [39]. This observation in serum gonadotropin concentrations among people living with $\mathrm{PrCa}$ indicates reduced $\mathrm{GnRH}$ secretion from the hypothalamus, up-regulation of PIP production by either or both the testes and prostate, and reduced GnRH receptors in the pituitary gland during malignancy resulting in decreased gonadotropin production and secretion from the anterior pituitary and prostate glands, respectively.

Oxidative stress has also been implicated in PrCa. Oxidative stress activates the extracellular signal-regulated kinase (ERK) subfamily, Akt, and the p38 subfamily leading to activation of various transcription factors involved in cell cycle to allow the tumour cells to rapidly progress through it [40]. Akt inhibits apoptosis by deactivating

Table 4 Serum trace elements among prostate cancer patients and controls

\begin{tabular}{lrrrl}
\hline Parameters & \multicolumn{1}{l}{ Test } & \multicolumn{1}{l}{ Control } & T value & $\boldsymbol{p}$ value \\
\hline Selenium $\mu \mathrm{g} / \mathrm{dL})$ & $61.50 \pm 3.44$ & $95.62 \pm 1.39$ & 6.554 & 0.000 \\
Zinc $(\mu \mathrm{g} / \mathrm{dL})$ & $4.33 \pm 0.33$ & $13.99 \pm 0.77$ & 13.518 & 0.000 \\
Magnesium $(\mu \mathrm{g} / \mathrm{dL})$ & $68.65 \pm 5.95$ & $168.13 \pm 7.23$ & 9.860 & 0.000 \\
Copper $(\mu \mathrm{g} / \mathrm{dL})$ & $0.13 \pm 0.00$ & $0.07 \pm 0.00$ & 7.960 & 0.000 \\
\hline
\end{tabular}

This table shows serum trace elements among PrCa patients. Values are Mean \pm Standard error of mean, and statistically significant difference was set at $p<0.05$ caspase-9 and Bcl-2-associated death promoter, promotes tumour cell survival, and suppresses antioxidant activity $[5,41]$. Result of serum antioxidant micronutrients revealed a significant decrease $(p<0.05)$ in serum selenium, zinc, magnesium, and a significant increase $(p<0.05)$ in serum copper among people living with $\mathrm{PrCa}$ when compared with normal subjects (Table 4). This finding corroborates the reported decrease in serum selenium, zinc, and magnesium and increase in serum copper among people living with $\mathrm{PrCa}[42,43]$. An inverse relationship was observed to exist between serum selenium, zinc, magnesium, and PrCa.

The use of ultrasonography in diagnosing $\mathrm{PrCa}$ is limited as $60-80 \%$ of PrCas are hypoechoic, $30-40 \%$ are isoechoic, and $1.5 \%$ are hyperechoic [44]. Benign conditions like benign prostatic hypertrophy, prostatitis, prostate atrophy, and prostate infarction may be hypoechoic on ultrasonography [45]. The ultrasonogram obtained from this study showed normal sized prostate $\left(8-10 \mathrm{~cm}^{3}\right.$ in volume) with homogeneous echotexture and regular outline in the control group, while an enlarged prostate (127-134 $\mathrm{cm}^{3}$ in volume) with heterogeneous echotexture and irregular outline was observed in the $\mathrm{PrCa}$ group (Fig. 1). This finding is suggestive of PrCa but not confirmatory due to limitations in the sensitivity and specificity of ultrasonography which range between 40 and 50\% for detecting PrCa [45].

Abnormal serum markers, abnormal DRE, and abnormal ultrasonography require histological confirmation. Prostate biopsy is needed for the understanding of pathological changes found during the DRE (a mass, asymmetry, an induration), raised serum PSA concentration, and evident structural changes of the prostate gland in order to obtain a histopathological diagnosis and to assess the

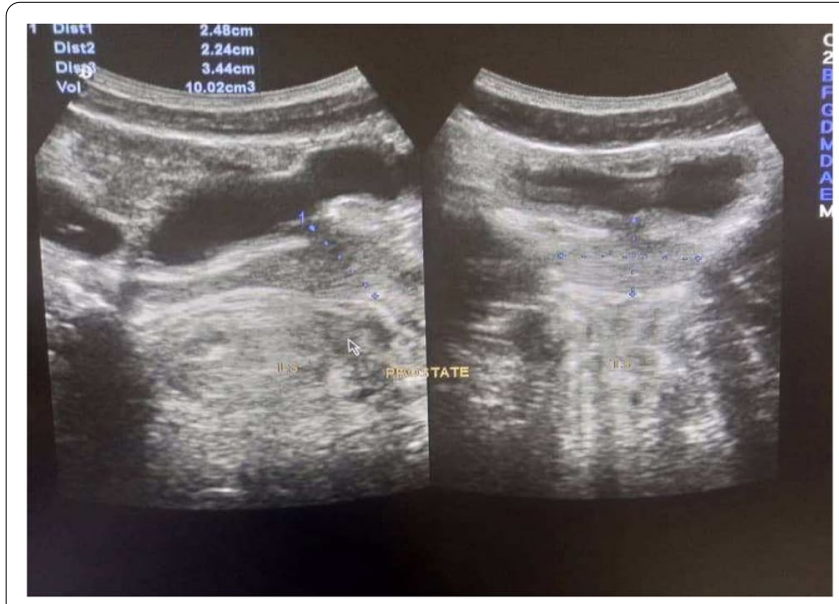

A

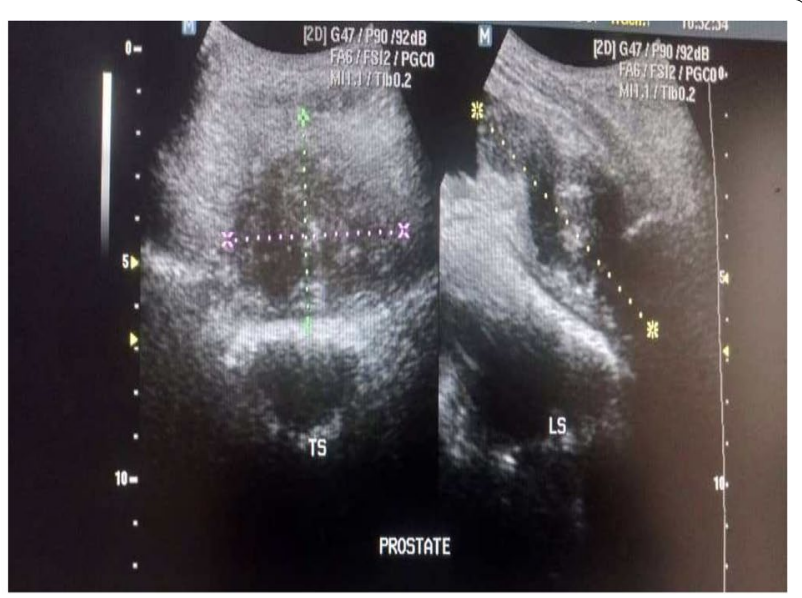

B

Fig. 1 The ultrasonography of the prostate in the control (A) and test (B) groups 
degree of cytoarchitectonic impairments among other reasons. Result obtained from this study revealed features of adenocarcinoma which occurred in about $92 \%$ (46 out of 50) of the test, while the remaining 8\% (4 out of 50) showed atrophic changes and features suggestive of prostatitis (inflammatory lymphocytic cells and cystic gland dilatation) and BPH (Fig. 2). Histological features seen in this study that are suggestive of prostate cancer include fragments of prostate tissue with effaced architecture due to malignant proliferation of prostatic ductal cells; small cells with hyperchromatic nuclear and scanty cytoplasm glands and fibromuscular stroma; variable single and fused glands with little intervening stroma; and cribriform pattern. Others showed prostatic glandular tissue with features of nodular hyperplasia with dense stroma reaction, absence focus of malignancy, several seminiferous tubules containing spermatozoa in various stages of development, demonstrable thick walls and dilated vessels, and atrophic testes consistent with age. Some of these findings are not limited to PrCa but are also observed in inflammatory and age-related changes in the prostate, implying that prostate biopsies do not always singly confirm $\mathrm{PrCa}$ as there are possible undetected PrCas, indicating imprecise nature of both the PSA test and biopsies when used alone.

\section{Conclusions}

Using results obtained from this study, it can be concluded that $\mathrm{PrCa}$ is associated with increased serum cortisol, testosterone, and copper and decreased serum LH, FSH, selenium, zinc, and magnesium concentrations. Blood PSA (TPSA and FPSA) and hormonal (testosterone, cortisol, gonadotropins) concentrations in conjunction with DRE and histologic studies could

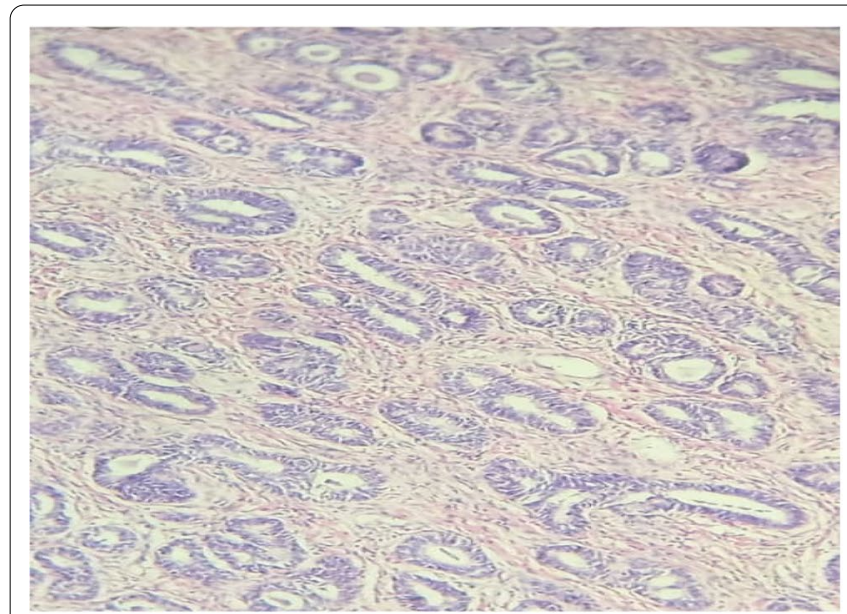

A

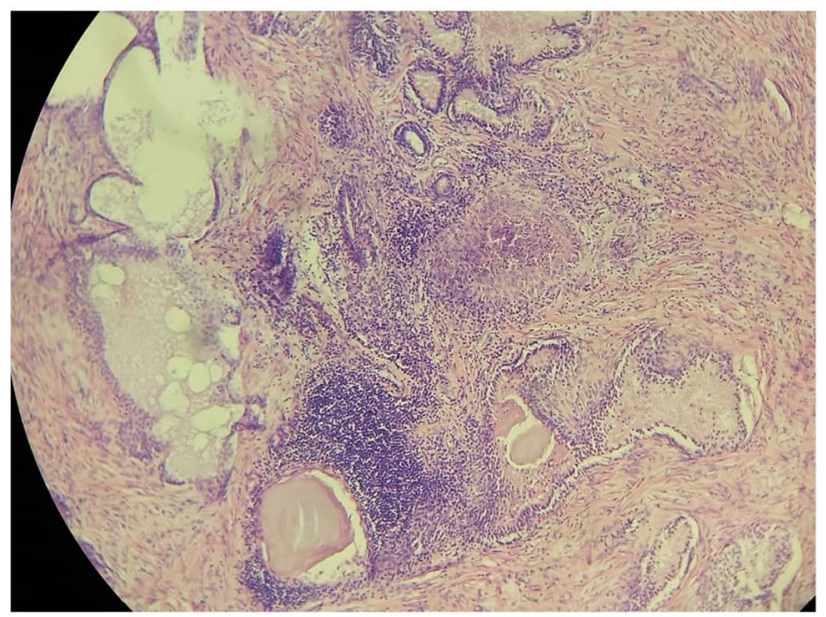

$\mathrm{C}$

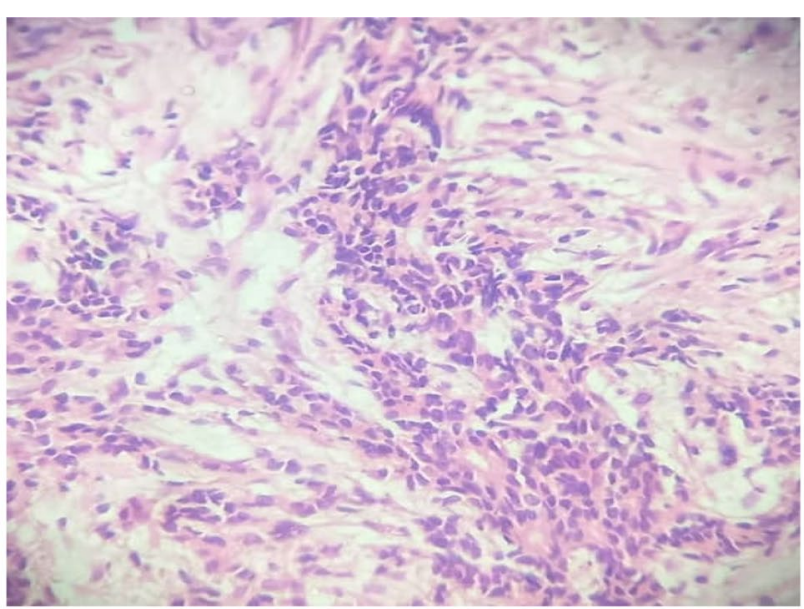

B

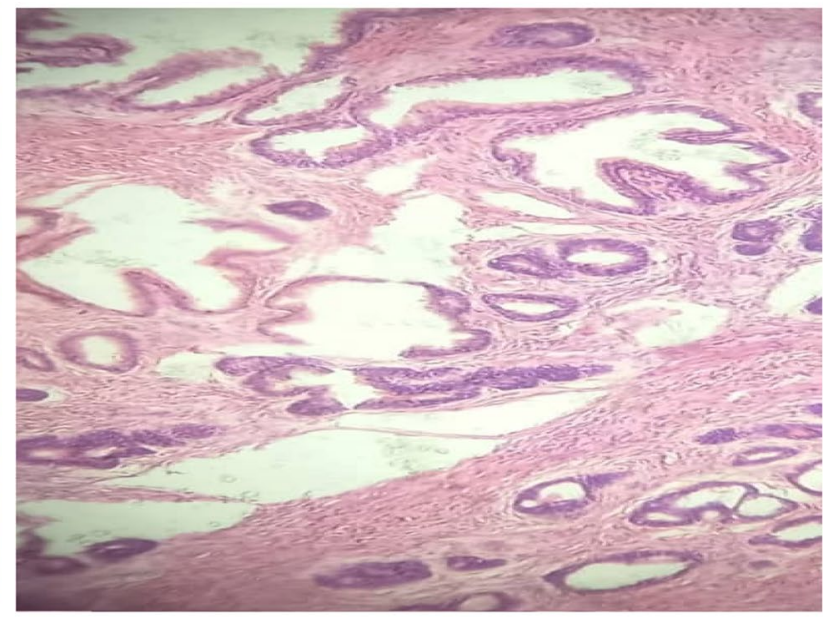

$\mathrm{D}$

Fig. 2 The histology of the prostate in the control and prostate cancer groups. A Normal prostate, B Prostate cancer, C Prostatitis, D Benign prostatic hyperplasia(Mag ×40) 
thus be explored to screen, confirm diagnosis, monitor treatment response, prognosticate $\mathrm{PrCa}$, and capture most $\mathrm{PrCa}$ cases that would have otherwise been missed. Also, the observed pattern of serum gonadotropins indicates the therapeutic use of LHRH agonist and $\mathrm{GnRH}$ antagonist in malignant prostate conditions.

\section{List of abbreviations}

PrCa: Prostate cancer; DRE: Digital rectal examination; ROS: Reactive oxygen species; BMI: Body mass index; WC: Waist circumference; WHR: Waist-hip ratio; $\mathrm{BPH}$ : Benign prostate hypertrophy; FSH: Follicle-stimulating hormone; LH: Luteinizing hormone; GnRH: Gonadotrophin-releasing hormone; PSA: Prostate-specific antigen; TPSA: Total prostate-specific antigen; FPSA: Free prostate-specific antigen; PSAD: Prostate-specific antigen density; PSAV: Prostate-specific antigen velocity; PHI: Prostate health index; ELISA: Enzymelinked immunosorbent assay; SPSS: Statistical package for the social sciences; ADT: Androgen deprivation therapy.

\section{Acknowledgements}

Not applicable.

\section{Authors' contributions}

OEW conceptualise the research and contributed to data collection and manuscript writing; OAA contributed to recruitment and physical examination of participants and contributed to manuscript revision; $\mathrm{AOO}$ contributed to recruitment of participants, data collection, and manuscript writing; and FAO contributed to recruitment of participants, data collection, and manuscript writing, while AAA contributed to data analysis, manuscript editing, and manuscript revision, and $\mathrm{OO}$ contributed to sample biopsy taking, slide preparation, and reporting. All authors have read and approved the manuscript.

\section{Funding}

This study was done without any external funding.

\section{Availability of data and materials}

The data collected, analysed, and used for this study are available from the corresponding author specifically on reasonable request.

\section{Declarations}

\section{Ethics and consent to participate}

The ethical approval was obtained from Research Ethical Committees of Olabisi Onabanjo University Teaching Hospital (OOUTH), Sagamu, with ethical approval number HREC/OOUTH/284/2019AP. Written informed consent was also obtained from all participants after the procedures, and potential benefits or risks had been explained to them at the beginning of the study. Participation was voluntary, and all information obtained was treated with utmost confidentiality

\section{Consent for publication}

Not applicable.

\section{Competing interests}

The authors declared that there are no competing interests.

\section{Author details}

'Department of Chemical Pathology and Immunology, Faculty of Basic Medical Sciences, Olabisi Onabanjo University, Sagamu Campus, Sagamu, Nigeria. ${ }^{2}$ Department of Urology, Faculty of Clinical Sciences, Olabisi Onabanjo University, Sagamu Campus, Sagamu, Nigeria. ${ }^{3}$ Department of Chemical Pathology, Bencarson College of Health and Medical Sciences, Babcock University, Ilisan, Nigeria. ${ }^{4}$ Radiodiagnostic Department, Federal Medical Centre, Ebute Metta, Lagos, Nigeria. ${ }^{5}$ Department of Morbid Anatomy and Histopathology, Olabisi Onabanjo University Teaching Hospital, Sagamu, Nigeria.
Received: 23 February 2021 Accepted: 11 July 2021

Published online: 23 July 2021

\section{References}

1. Mohammed AZ, Edino ST, Ochicha O, Gwarzo AK, Samaila AA (2008) Cancer in Nigeria: a 10-year analysis of the Kano cancer registry. Niger J Med 17(3):280-284

2. Fradet Y, Klotz L, Trachtenberg J, Zlotta A (2009) The burden of prostate cancer in Canada. Can Urol Assoc J 3(2):S92-S100

3. Hu H, Odedina FT, Reams RR, Lissaker CTK, Xu X (2015) Racial differences in age-related variations of testosterone levels among US males: potential implications for prostate cancer and personalized medication. J Racial Ethn Health Disparities 2:69-76

4. Vermeulen A (1973) The physical state of testosterone in plasma. In: James VHT, Serio M, Maratini L (eds) The endocrine function of the htestis. Academic Press, New York, pp 157-170

5. Reuter S, Gupta SC, Chaturvedi MM, Aggarwal BB (2010) Oxidative stress, inflammation, and cancer: how are they linked? Free Radical Biol Med 49(11):1603-1616

6. Krishna D, Chikezie OM, Yi L (2020) The role of oxidative stress in cancer. Nov Appro in Can Study 4(2):350-355

7. Pentyala S, Whyard T, Pentyala S, Muller J, Pfail J, Parmar S, Helquero CG, Khan S (2016) Prostate cancer markers: an update (Review). Biomed Rep 4:263-268

8. Turpeinen U, Hämäläinen E (2013) Determination of cortisol in serum, saliva and urine. Best Pract Res Clin Endocrinol Metab 27(6):795-801

9. Horton R, Kato T, Sherins R (1967) A rapid method for the estimation of testosterone in male plasma. Steroid 10:245-256

10. Beastall GH, Ferguson KM, St J, O'reilly D, Seth J, Sheridan B, (1987) Assays for follicle stimulating hormone and luteinising hormone: guidelines for the provision of a clinical biochemistry service. Ann Clin Biochem 24:246-262

11. Metcalf E (1987) Atomic absorption and emission spectroscopy. Wiley, New York, pp 137-143

12. Kaneko JJ (1999) Clin Biochem of Animal, 4th edn. Academic Press Inc., New York, p 932

13. Zhang GM, Zhu Y, Chen HT, Han CT, Liu F, Xu JF, Ye DW (2015) Association between the body mass index and prostate cancer at biopsy is modified by genetic risk. Medicine 94(42):e1603

14. Schuurman AG, Goldbohm RA, Dorant E, van den Brandt PA (2000) Anthropometry in relation to prostate cancer risk in the Netherlands Cohort Study. Am J Epidemiol 151:541-549

15. Lavalette C, Trétarre B, Rebillard X, Lamy PJ, Cénée S, Menegaux F (2018) Abdominal obesity and prostate cancer risk: epidemiological evidence from the EPICAP study. Oncotarget 9(77):34485-34494

16. Ted AS, Kathleen YW, Robert LG III (2007) The effect of body mass index on PSA, prostate cancer development, screening and treatment. Nat Clin Pract Urol 4(11):605-614

17. Stamey TA, Yang N, Hay AR, McNeal JE, Freiha FS, Redwine E (1987) Prostate-specific antigen as a serum marker for adenocarcinoma of the prostate. N Engl J Med 317(15):909-916

18. Finne P, Finne R, Bangma C, Hugosson J, Hakama M, Auvinen A et al (2004) Algorithms based on prostate-specific antigen (PSA), free PSA, digital rectal examination and prostate reduce false-positive PSA results in prostate cancer screening. Int J Cancer 111(2):310-315

19. Mikolajczyk SD, Rittenhouse HG (2004) Tumor-associated forms of prostate specific antigen improve the discrimination of prostate cancer from benign disease. Rinsho Byori 52(3):223-230

20. Williams G (2012) Aromatase up-regulation, insulin and raised intracellular oestrogens in men, induce adiposity, metabolic syndrome and prostate disease, via aberrant ER-a and GPER signalling. Mol Cell Endocrinol 351:269-278

21. Bibiana F, Halina G, Diego G, Nahuel FM, Esteban MR, Viviana M, Miguel AL, Osvaldo M, Gabriela B (2016) Prostate cancer, high cortisol levels and complex hormonal interaction. Asian Pac J Cancer Prev 17(7):3167-3171

22. Antoni MH, Lutgendorf SK, Cole SW, Dhabhar FS, Sephton SE, McDonald PG, Stefanek M, Sood AK (2006) The influence of bio-behavioural factors on tumour biology: pathways and mechanisms. Nat Rev Cancer 6(3):240-248 
23. Mravec B, Gidron Y, Hulin I (2008) Neurobiology of cancer: Interactions between nervous, endocrine and immune systems as a base for monitoring and modulating the tumorigenesis by the brain. Semin Cancer Biol 18:150-163

24. Dieudonné M, Sammari A, Dos Santos E, Leneveu MC, Giudicelli Y, Pecquery R (2006) Sex steroids and leptin regulate 11-hydroxysteroid dehydrogenase 1 and p450 aromatase expressions in human preadipocytes: sex specificities. J Steroid Biochem Mol Biol 99:189-196

25. Williams $G$ (2010) The role of oestrogen in the pathogenesis of obesity, type 2 diabetes, breast cancer and prostate disease. Eur J Cancer Prev 19:256-271

26. Yano M, Imamoto T, Suzuki H, Fukasawa S, Kojima S, Komiya A, Naya Y, Ichikawa T (2007) The clinical potential of pretreatment serum testosterone level to improve the efficiency of prostate cancer screening. Eur Urol 51:375-380

27. Pierorazio P, Ferrucci L, Kettermann A, Longo D, Metter E, Carter H (2010) Serum testosterone is associated with aggressive prostate cancer in older men: results from the Baltimore longitudinal study of aging. BJU Int 105:824-829

28. Garcia-Cruz E, Piqueras M, Ribal M, Huquet J, Serapiao R, Peri L, Izquierdo L, Alcaraz A (2012) Low testosterone level predicts prostate cancer in rebiopsy in patients with high grade prostatic intraepithelial neoplasia. BJU Int 110:E199-E202

29. Mearini L, Zucchi A, Nunzi E, Villirillo T, Bini V, Porena M (2013) Low serum testosterone levels are predictive of prostate cancer. World J Urol 31:247-252

30. Roddam A, Allen N, Appleby P, Key T (2008) Endogenous sex hormones and prostate cancer: a collaborative analysis of 18 prospective studies. J Natl Cancer Inst 100:170-183

31. Muller R, Gerber L, Moreira D, Andriole G, Castro-Santamaria R, Freedland S (2012) Serum testosterone and dihydrotestosterone and prostate cancer risk in the placebo arm of the reduction by dutasteride of prostate cancer events trial. Eur Urol 62:757-764

32. Claude C, Schulman Jl, Juan M, Jack AS, Francesco M, Piotr LC (2010) Testosterone measurement in patients with prostate cancer. Eur Urol 58(1):65-74

33. Harman SM, Metter EJ, Tobin JD, Pearson J, Blackman MR (2001) Longitudinal effects of aging on serum total and free testosterone levels in healthy men. J Clin Endocrinol Metab 86(2):724-731

34. Wu FC, Tajar A, Pye SR, Silman AJ, Finn JD, O’Neill TW, Bartfai G, Casanueva F, Forti G, Giwercman A et al (2008) Hypothalamic-pituitary-testicular axis disruptions in older men are differentially linked to age and modifiable risk factors: the European male aging study. J Clin Endocrinol Metab 93:2737-2745

35. Saboor ASA, Kumar S, Barber TM (2013) The role of obesity and type 2 diabetes mellitus in the development of male obesity-associated secondary hypogonadism. Clin Endocrinol 78:330-337

36. Ahern T, Swiecicka A, Eendebak RJ, Carter EL, Finn JD, Pye SR, O'Neill TW, Antonio L, Keevil B, Bartfai G et al (2016) Natural history, risk factors and clinical features of primary hypogonadism in ageing men: longitudinal data from the European male aging study. Clin Endocrinol 85:891-901

37. Mariani S, Salvatori L, Basciani S, Arizzi M, Franco G, Petrangeli E, Spera G, Gnessi L (2006) Expression and cellular localization of follicle-stimulating hormone receptor in normal human prostate, benign prostatic hyperplasia and prostate cancer. J Urol 175(6):2072-2077

38. Catarinicchia S, Crawford ED (2016) The role of FSH in prostate cancer: a case report. Urol Case Rep 7(2016):23-25

39. Yu G, Mylander C, Traish A, Jarrett T (2012) Circulating levels of gonadotropins before and after prostate ablation in cancer patients, circulating levels of gonadotropins before and after prostate ablation in cancer patients. Horm Mol Biol Clin Invest 11(3):355-362

40. Xia Z, Dickens M, Raingeaud J, Davis RJ, Greenberg ME (1995) Opposing effects of ERK and JNK-p38 MAP kinases on apoptosis. Science 270(5240):1326-1331

41. Los M, Maddika S, Erb B, Schulze-Osthoff K (2009) Switching Akt: from survival signalling to deadly response. BioEssays 31(5):492-495

42. Dai Q, Motley SS, Smith JA Jr, Concepcion R, Barocas D, Byerly S, Fowke JH (2011) Blood magnesium, and the interaction with calcium, on the risk of high-grade prostate cancer. PLoS ONE 6(4):e18237

43. Saleh AK, Saleh HM, Adly AA, Abdelkhaliq AMN (2020) Serum levels of selenium, zinc, copper, manganese, and iron in prostate cancer patients. Curr Urol 14:44-49

44. Ganie FA, Wanie MS, Ganie SA, Lone H, Gani M, Mir MF, Khan NA (2014) Correlation of transrectal ultrasonographic findings with histopathology in prostatic cancer. J Educ Health Promot 3:38

45. Chen FK, de Castro Abreu AL, Palmer SL (2016) Utility of ultrasound in the diagnosis, treatment, and follow-up of prostate cancer: state of the art. J Nucl Med 57(3):13S-18S

\section{Publisher's Note}

Springer Nature remains neutral with regard to jurisdictional claims in published maps and institutional affiliations.

\section{Submit your manuscript to a SpringerOpen ${ }^{\circ}$ journal and benefit from:}

- Convenient online submission

- Rigorous peer review

- Open access: articles freely available online

- High visibility within the field

Retaining the copyright to your article

Submit your next manuscript at springeropen.com 